\title{
Design and Baseline Patient Characteristics of the Prospective, Observational, Multicenter and Multinational Cohort Study Comparing Radiofrequency with Cryoablation for Pulmonary Vein Isolation in Patients with Atrial Fibrillation- The Freeze Cohort Study
}

\author{
Ellen Hoffmann', Uwe Dorwarth1, Karl Heinz Kuck², Jürgen Vogt ${ }^{3}$, Malte Kuniss ${ }^{4}$, \\ Steffen Schneider ${ }^{5}$, Jürgen Tebbenjohanns6, Kyong Ryul Julian Chun7, Dietrich Andresen ${ }^{8}$, \\ Stefan Spitzer ${ }^{9}$, Thorsten Lewalter ${ }^{10}$, Stephan Willems ${ }^{11}$, Johannes Brachmann ${ }^{12}$, \\ Christoph Stellbrink ${ }^{13}$, Bernhard Rauch ${ }^{*}$, Jochen Senges ${ }^{5}$ \\ ${ }^{1}$ Department of Cardiology, Klinikum Bogenhausen, Munich, Germany \\ ${ }^{2}$ Department of Cardiology, Asklepios Klinik St. Georg, Hamburg, Germany \\ ${ }^{3}$ Ruhr University Bochum, Bad Oeynhausen, Germany \\ ${ }^{4}$ Department of Cardiology, Kerckhoff Klinik, Bad Nauheim, Germany \\ ${ }^{5}$ Stiftung Institut für Herzinfarktforschung, Ludwigshafen am Rhein, Germany \\ ${ }^{6}$ Klinikum Hildesheim, Hildesheim, Germany \\ ${ }^{7}$ Center for Cardiology and Angiology Frankfurt, CCB, Frankfurt am Main, Germany \\ ${ }^{8}$ Department of Cardiology, Vivantes Klinikum am Urban, Berlin, Germany \\ ${ }^{9}$ Praxisklinik Herz und Gefäße, Dresden, Germany \\ ${ }^{10}$ Department of Cardiology, Isar Herzzentrum, Munich, Germany \\ ${ }^{11}$ Department of Cardiology, Universitäres Herzzentrum Hamburg, Hamburg, Germany \\ ${ }^{12}$ Department of Cardiology, Klinikum Coburg, Coburg, Coburg \\ ${ }^{13}$ Department of Cardiology, Klinikum Bielefeld, Bielefeld, Germany \\ Email: ${ }^{*}$ rauch.b@stiftung-ihf.de
}

Received 31 July 2014; revised 29 August 2014; accepted 25 September 2014

Copyright (C) 2014 by authors and Scientific Research Publishing Inc.

This work is licensed under the Creative Commons Attribution International License (CC BY). http://creativecommons.org/licenses/by/4.0/

\section{(c) (i) Open Access}

\footnotetext{
${ }^{*}$ Corresponding author.

How to cite this paper: Hoffmann, E., et al. (2014) Design and Baseline Patient Characteristics of the Prospective, Observational, Multicenter and Multinational Cohort Study Comparing Radiofrequency with Cryoablation for Pulmonary Vein Isolation in Patients with Atrial Fibrillation-The Freeze Cohort Study. International Journal of Clinical Medicine, 5, 1161-1172. http://dx.doi.org/10.4236/ijcm.2014.519149
} 


\section{Abstract}

Aims: The FREEZE-cohort study (NCT 01360008) is a prospective observational, multicenter and multinational study to evaluate safety and effectiveness of cryoballoon ablation for pulmonary vein isolation as compared to radiofrequency ablation in patients with paroxysmal or persistent atrial fibrillation (lasting <one year) under the conditions of clinical routine. Methods and Results: The study started in 2011 and anticipates inclusion up to 2000 patients in each of the two treatment groups. A total of 37 centers from 8 countries worldwide, all experienced in at least one of the two ablation techniques, participate in the study. The primary outcome parameter of the study is defined as atrial fibrillation recurrence rate during twelve months of follow-up. Secondary outcome parameters include primary success rates, complication rates in general, specific complications with respect to phrenic nerve palsy and pulmonary vein stenosis, radiation exposure, clinical course including death and repeat ablation. Finally specific procedural aspects will be evaluated in a descriptive manner. Preliminary data of the first 1882 patients show that in clinical practice cryoablation is preferentially performed in patients with paroxysmal atrial fibrillation, whereas application of radiofrequency ablation is equally distributed between patients with persistent and paroxysmal atrial fibrillation. Conclusion: Based on multi-center and multi-national data the FREEZE-cohort study will provide important information on long-term efficacy, clinical effectiveness, complication rates and procedural differences between atrial fibrillation patients treated with either cryoablation or radiofrequency ablation.

\section{Keywords}

Atrial Fibrillation, Catheter Ablation, Cryoballoon Ablation, Radiofrequency Ablation, Registry

\section{Introduction}

Atrial fibrillation (AF) affects around 4.5 million people in the European Union, and is well-known as a major cause of stroke. AF adversely affects quality of life and is associated with increased morbidity and mortality [1]. With the ablation and subsequent isolation of pulmonary vein foci Haïssaguerre et al. in 1998 introduced a novel treatment strategy targeting the elimination of the source of some atrial arrhythmias [2]. Meanwhile, catheter ablation for curative treatment of AF is increasingly used in specialized centers. However, clinical data published so far show variable results depending on the ablation method used, patient's selection and follow-up. Although a recent survey reported an average efficacy of 75.9\% freedom from symptomatic AF after a single ablation procedure and during a follow-up of 12 months (patients with ongoing anti-arrhythmic drug therapy included), variation of success rate was high [3]. Moreover, circumferential radiofrequency ablation (RF) remains technically challenging with a significant number of complications [4]. Therefore, innovative and less challenging technologies have been developed to increase safety and success rate of pulmonary vein isolation (PVI).

One of the promising new technologies for PVI is the cryoballoon technology (CA; CryoCath, Medtronic, U.S.). The cryoballoon technique was shown to be feasible and safe during short- and long-term follow-up [5]-[7]. As complete occlusion of the PVs is the key for treatment success two sizes of the cryoballoon (23 mm and $28 \mathrm{~mm}$ ) have been developed for optimal adjustment to the ostial diameters of the pulmonary veins. The current clinical experience and recent scientific data with respect to cryoablation for AF are summarized in Table 1. On the basis of these studies the primary treatment success can be regarded as high and comparable to radiofrequency ablation [8]-[15]. However, most studies included a relatively small number of patients. In addition the studies show considerable variations with respect to long-term success and complications of CA. Therefore more scientific data are needed to evaluate procedural efficacy and clinical efficiency of both methods under well controlled scientific conditions on one hand, but also under the conditions of all day clinical practice on the other hand. By this way the individually best approach for each patient designated for PVI may be defined more exactly in future. Whereas the projected randomized controlled trial "FIRE and ICE" [16] concentrates on the procedural efficacy of both methods, the primary aim of the present prospective FREEZE COHORT study is to reflect their efficiency in clinical routine. 
Table 1. Selection of studies evaluating safety and success cryo-balloon ablation for treatment of paroxysmal and persistent atrial fibrillation.

\begin{tabular}{|c|c|c|c|c|c|c|c|c|}
\hline Publication & $\begin{array}{l}\text { Kojodjojo P. } \\
\text { et al. } 2010 \text { [8] }\end{array}$ & $\begin{array}{l}\text { Vogt J. et al. } \\
2013 \text { [9] }\end{array}$ & $\begin{array}{l}\text { Packer D.L. et } \\
\text { al. } 2013 \text { [10] }\end{array}$ & $\begin{array}{l}\text { Schmidt M. et } \\
\text { al. } 2013 \text { [11] }\end{array}$ & $\begin{array}{l}\text { Bordignon S. e } \\
\text { al. } 2013 \text { [12] }\end{array}$ & $\begin{array}{l}\text { etPokushalov E. } \\
\text { et al. } 2013 \text { [13] }\end{array}$ & $\begin{array}{l}\text { Malmborg H. } \\
\text { et al. } 2013 \text { [14] }\end{array}$ & $\begin{array}{l}\text { Pérez- } \\
\text { Castellano N. } \\
\text { et al. } 2014 \text { [15] }\end{array}$ \\
\hline Study design & $\begin{array}{l}\text { Single center } \\
\text { cohort study }\end{array}$ & $\begin{array}{l}\text { Single center, } \\
\text { prospective } \\
\text { observational } \\
\text { study }\end{array}$ & $\begin{array}{l}\text { Multi center } \\
\text { RCT }\end{array}$ & $\begin{array}{l}\text { German } \\
\text { multi-center } \\
\text { prospective } \\
\text { cohort study }\end{array}$ & $\begin{array}{l}\text { Single center } \\
\text { RCT }\end{array}$ & $\begin{array}{l}\text { Single center } \\
\text { RCT, } \\
\text { Patients } \\
\text { blinded }\end{array}$ & $\begin{array}{l}\text { Single center } \\
\text { RCT }\end{array}$ & $\begin{array}{l}\text { Single center } \\
\text { RCT }\end{array}$ \\
\hline Intervention & CA vs RF & $\mathrm{CA}$ & CA vs AAD & CA vs RF & CA vs LB & CA vs RF & CA vs RF & CA vs RF \\
\hline $\begin{array}{l}\text { Number of } \\
\text { patients }\end{array}$ & $\begin{array}{l}\text { CA: } 124 \\
\text { RF: } 53\end{array}$ & CA: 605 & $\begin{array}{l}\text { CA: } 163 \\
\text { AAD: } 82\end{array}$ & $\begin{array}{l}\text { CA: } 905 \\
\text { RF: } 2870\end{array}$ & $\begin{array}{l}\text { CA: } 70 \\
\text { LB: } 70\end{array}$ & $\begin{array}{l}\text { CA: } 40 \\
\text { RF: } 40\end{array}$ & $\begin{array}{l}\text { CA: } 54 \\
\text { RF: } 56\end{array}$ & $\begin{array}{l}\text { CA: } 25 \\
\text { CA: } 25\end{array}$ \\
\hline $\begin{array}{l}\text { Major } \\
\text { inclusion } \\
\text { criteria }\end{array}$ & $\begin{array}{l}\text { Symptomatic } \\
\text { PAF }(\mathrm{n}=90) \\
\text { or } \\
\text { early persistent } \\
\text { and AAD } \\
\text { refractory AF } \\
(\mathrm{n}=34)\end{array}$ & $\begin{array}{l}\text { Symptomatic } \\
\text { PAF (n = } \\
579) \text { or } \\
\text { tt early } \\
\text { symptomatic } \\
\text { persistent AF } \\
(\mathrm{n}=26)\end{array}$ & $\begin{array}{l}\text { Symptomatic } \\
\text { PAF (78\%) } \\
\text { or } \\
\text { symptomatic } \\
\text { persistent AF } \\
(22 \%) ; \\
\text { failure of at } \\
\text { least one AAD }\end{array}$ & $\begin{array}{l}\text { Symptomatic } \\
\text { PAF; } \\
\text { first ablation; } \\
\text { patients } \\
\text { refractory to at } \\
\text { least one AAD }\end{array}$ & $\begin{array}{l}\text { PAF refractory } \\
\text { to at least one } \\
\text { AAD; } \\
\text { age } 18 \text { - } 75 \mathrm{y} \text {; } \\
\text { no prior PVI; } \\
\text { LA < } 50 \mathrm{~mm} \text {; } \\
\text { LVEF > 45\% }\end{array}$ & $\begin{array}{l}\text { Patients after } \\
\text { previously } \\
\text { failed first } \\
\text { RF-ablation; } \\
\text { CA or RF as a } \\
\text { second ablation } \\
\text { procedure }\end{array}$ & $\begin{array}{l}\text { Patients with } \\
\text { AF, treatment } \\
\text { failure of at } \\
\text { least one AAD, } \\
\text { and scheduled } \\
\text { for ablation }\end{array}$ & $\begin{array}{l}\text { Symptomatic } \\
\text { recurrent PAF } \\
\text { refractory to } \\
\text { AAD and con- } \\
\text { 'sidered for the } \\
\text { first PV isola- } \\
\text { tion }\end{array}$ \\
\hline $\begin{array}{l}\text { Primary } \\
\text { endpoints } \\
\text { (selection) }\end{array}$ & $\begin{array}{l}\text { Freedom from } \\
\text { AF at } 12 \text { mo } \\
\text { after a single } \\
\text { procedure }\end{array}$ & $\begin{array}{l}\text { Successful } \\
\text { PVI of all PV }\end{array}$ & $\begin{array}{l}\text { Freedom from } \\
\text { AF after } \\
\text { blanking } \\
\text { period; } \\
V \text { freedom from } \\
\text { adverse events } \\
\text { during } 12 \text { mo } \\
\text { of follow-up }\end{array}$ & $\begin{array}{l}\text { Procedural } \\
\text { outcome; } \\
\text { Complication } \\
\text { rates }\end{array}$ & $\begin{array}{l}\text { AF recurrence } \\
90 \text { - } 365 \text { days } \\
\text { after index } \\
\text { ablation; } \\
\text { procedural } \\
\text { complications }\end{array}$ & $\begin{array}{l}\text { AF recurrence } \\
\text { rate }\end{array}$ & $\begin{array}{l}\text { Freedom from } \\
\text { AF without } \\
\text { taking AAD } \\
12 \text { mo after } \\
\text { ablation } \\
\text { excluding a } \\
\text { blanking } \\
\text { period of } \\
3 \text { mo }\end{array}$ & $\begin{array}{l}\text { Freedom from } \\
\text { AF without } \\
\text { taking AAD } \\
12 \text { mo after } \\
\text { ablation } \\
\text { excluding a } \\
\text { blanking } \\
\text { period of } \\
3 \text { mo }\end{array}$ \\
\hline \multicolumn{9}{|c|}{ Baseline characteristics } \\
\hline Age (years) & $\begin{array}{l}\text { CA: } \\
57.3 \pm 9.4 \\
\text { RA: } \\
59.3 \pm 9.7^{*} \\
(\text { mean } \pm \text { SD) }\end{array}$ & $\begin{array}{l}59 \pm 11 \\
(\text { mean } \pm \text { SD) }\end{array}$ & $\begin{array}{l}\text { Total study } \\
\text { Population: } \\
57 \pm 9 \\
\text { (mean } \pm \text { SD) }\end{array}$ & $\begin{array}{l}\text { CA: } 62 \\
\text { RF: } 63\end{array}$ & $\begin{array}{l}\text { CA: } 63 \pm 12 \\
\text { LB: } 63 \pm 9 \\
(\text { mean } \pm \text { SD) }\end{array}$ & $\begin{array}{l}\text { CA: } 56 \pm 9 \\
\text { RF: } 56 \pm 11 \\
(\text { mean } \pm \text { SD) }\end{array}$ & $\begin{array}{l}\mathrm{CA}: 59 \pm 9 \\
\mathrm{RF}: 62 \pm 7\end{array}$ & $\begin{array}{l}\text { CA: } \\
58(45-62) \\
\text { RF: } \\
56(40-61)\end{array}$ \\
\hline $\begin{array}{l}\text { Female } \\
\text { gender (\%) }\end{array}$ & $\begin{array}{l}\text { CA: } 25^{*} \\
\text { RF: } 23\end{array}$ & CA: 32.9 & $\begin{array}{l}\text { CA + AAD: } \\
22.9\end{array}$ & $\begin{array}{l}\text { CA: } 35.7 \\
\text { RF: } 37.3\end{array}$ & $\begin{array}{l}\text { CA: } 30 \\
\text { LB: } 39\end{array}$ & $\begin{array}{l}\text { CA: } 23 \\
\text { RF: } 18\end{array}$ & $\begin{array}{l}\text { CA: } 20 \\
\text { RF: } 29\end{array}$ & $\begin{array}{l}\text { CA: } 32 \\
\text { RF: } 12\end{array}$ \\
\hline HTN (\%) & $\begin{array}{l}\text { CA: } 47^{*} \\
\text { RA: } 26\end{array}$ & CA: 42 & $\begin{array}{l}\text { CA + AAD: } \\
42\end{array}$ & $\begin{array}{l}\text { CA: } 57.8 \\
\text { RF: } 55.8\end{array}$ & $\begin{array}{l}\text { CA: } 63 \\
\text { LB: } 60\end{array}$ & $\begin{array}{l}\text { CA: } 15 \\
\text { RF: } 17\end{array}$ & $\begin{array}{l}\text { CA: } 41 \\
\text { RF: } 63\end{array}$ & $\begin{array}{l}\text { CA: } 32 \\
\text { RF: } 24\end{array}$ \\
\hline LA size (mm) & $\begin{array}{l}\text { CA: } 39.6 \pm 7.1 \\
\text { RA: } 41.5 \pm 6.5\end{array}$ & $\frac{1}{5} 42.1 \pm 5.6$ & $\begin{array}{l}\text { CA + AAD: } \\
41 \pm 5\end{array}$ & $\mathrm{nr}$ & $\begin{array}{l}\text { CA: } 39.8 \pm 3.8 \\
\text { LB: } 39.9 \pm 4.9 \\
(\text { mean } \pm S D)\end{array}$ & $\begin{array}{l}\mathrm{CA}: 46 \pm 5 \\
\mathrm{RF}: 48 \pm 7 \\
(\text { mean } \pm \mathrm{SD})\end{array}$ & $\begin{array}{l}\text { CA: } 40 \pm 6 \\
\text { RF: } 42 \pm 5\end{array}$ & $\mathrm{nr}$ \\
\hline LVEF (\%) & $\begin{array}{l}\text { CA: } 65.0 \pm 8.8 \\
\text { RA: } 60.3 \pm 7.3\end{array}$ & $\begin{array}{l}87.1 \pm 4.0 \\
3\end{array}$ & $\begin{array}{l}\text { CA + AAD: } \\
60 \pm 6\end{array}$ & $\begin{array}{l}\frac{\text { Patients with }}{\text { LVEF }>50 \%} \\
\text { CA: } 92.9 \% \\
\text { RF: } 91.4 \%\end{array}$ & $\begin{array}{l}\mathrm{CA}: 63 \pm 4 \\
\mathrm{LB}: 63 \pm 6 \\
(\text { mean } \pm \mathrm{SD})\end{array}$ & $\begin{array}{l}\text { CA: } 58 \pm 5 \\
\text { RF: } 57 \pm 6 \\
(\text { mean } \pm S D)\end{array}$ & $\mathrm{nr}$ & $\mathrm{nr}$ \\
\hline \multicolumn{9}{|l|}{ Outcome } \\
\hline $\begin{array}{l}\text { Fluoroscopy } \\
\text { time (min) }\end{array}$ & $\begin{array}{l}\mathrm{CA}: 27 \pm 9 \\
\mathrm{RA}: 62 \pm 36 \\
(\text { mean } \pm \mathrm{SD})\end{array}$ & $\begin{array}{l}25.2 \\
(19.6 / 32.2)\end{array}$ & 63 & $\begin{array}{l}\text { CA: } \\
34(26-46) \\
\text { RF: } \\
24(16-37)\end{array}$ & $\begin{array}{l}\text { CA: } 21 \pm 9 \\
\text { LB: } 15 \pm 6 \\
(\text { mean } \pm \text { SD) }\end{array}$ & $\begin{array}{l}\text { CA: } 29 \pm 11 \\
\text { RF: } 21 \pm 17 \\
(\text { mean } \pm \text { SD) }\end{array}$ & $\begin{array}{l}\text { CA: } 32 \pm 16 \\
\text { RF: } 47 \pm 17 \\
(m e a n \pm S D)\end{array}$ & $\begin{array}{l}\mathrm{CA}: 45 \pm 16 \\
\mathrm{RF}: 45 \pm 16 \\
(\text { mean } \pm \mathrm{SD})\end{array}$ \\
\hline $\begin{array}{l}\text { Procedural } \\
\text { complications, } \\
\text { total: }\end{array}$ & $\begin{array}{l}\text { CA: } 3 \\
\text { RF: } 2\end{array}$ & $\begin{array}{l}\text { CA: } 43 \text { out of } \\
605(7.1 \%)\end{array}$ & $\begin{array}{l}\text { CA: } 54 \text { out of } \\
163(33 \%)\end{array}$ & $\begin{array}{l}\text { CA: } 23 \text { out of } \\
849(2.7 \%) \\
\text { RF: } 118 \text { out of } \\
2578(4.6 \%)\end{array}$ & $\begin{array}{l}\text { CA: } 6 \\
\text { LB: } 9\end{array}$ & $\mathrm{nr}$ & $\begin{array}{l}\text { CA: } 4 \\
\text { RF: } 1\end{array}$ & $\begin{array}{l}\text { CA: } 2 \\
\text { RF: } 1\end{array}$ \\
\hline Death & $\begin{array}{l}\text { CA: } 0 \\
\text { RF: } 0\end{array}$ & CA: 0 & $\begin{array}{l}\text { CA: } 1 \\
\text { AAD: } 0\end{array}$ & $\begin{array}{l}\text { CA: } 0 \\
\text { RF: } 0\end{array}$ & $\begin{array}{l}\text { CA: } 0 \\
\text { LB: } 0\end{array}$ & $\mathrm{nr}$ & $\begin{array}{l}\text { CA: } 0 \\
\text { RF: } 0\end{array}$ & $\begin{array}{l}\text { CA: } 0 \\
\text { RF: } 0\end{array}$ \\
\hline$A M I$ & $\begin{array}{l}\text { CA: } 0 \\
\text { RF: } 0\end{array}$ & CA: 0 & $\begin{array}{l}\text { CA: } 2 \\
\text { AAD: } 0\end{array}$ & $\begin{array}{l}\text { CA: } 0.1 \% \\
\text { RF: } 0\end{array}$ & $\mathrm{nr}$ & $\mathrm{nr}$ & $\begin{array}{l}\text { CA: } 0 \\
\text { RF: } 0\end{array}$ & $\begin{array}{l}\text { CA: } 0 \\
\text { RF: } 0\end{array}$ \\
\hline Stroke/TIA & $\begin{array}{l}\text { CA: } 0 \\
\text { RF: } 0\end{array}$ & CA: 2 & $\begin{array}{l}\text { CA: } 7 \\
\text { AAD: } 0\end{array}$ & $\begin{array}{l}\text { CA: } 0.3 \%^{* *} \text { ) } \\
\text { RF: } 0.3 \%\end{array}$ & $\begin{array}{l}\text { CA: } 0 \\
\text { LB: } 1\end{array}$ & $\begin{array}{l}\text { CR: } 0 \\
\text { RF: } 0\end{array}$ & $\begin{array}{l}\text { CA: } 0 \\
\text { RF: } 0\end{array}$ & $\begin{array}{l}\text { CA: } 0 \\
\text { RF: } 0\end{array}$ \\
\hline PE/tamp & $\begin{array}{l}\text { CA: } 0 / 1 \\
\text { RF: } 0 / 2\end{array}$ & CA: 2 & $\begin{array}{l}\text { CA: } 1 \\
\text { AAD: } 0\end{array}$ & $\begin{array}{l}\text { CA: } 0.8 \% \\
\text { RF: } 1.4 \%\end{array}$ & $\begin{array}{l}\text { CA: } 0 \\
\text { LB: } 1\end{array}$ & $\mathrm{nr}$ & $\begin{array}{l}\text { CA: } 0 \\
\text { RF: } 0\end{array}$ & $\begin{array}{l}\left.\text { CA: } 1^{* * * *}\right) \\
\text { RF: } 0\end{array}$ \\
\hline
\end{tabular}




\begin{tabular}{|c|c|c|c|c|c|c|c|c|}
\hline \multicolumn{9}{|l|}{ Continued } \\
\hline Transient PNP & $\begin{array}{l}\text { CA: } 2 \\
\text { RF: } 0\end{array}$ & CA: 15 & $\begin{array}{l}\text { CA: } 22 \\
(=13 \%) \\
\text { AAD: } 0\end{array}$ & $\begin{array}{l}\text { CA: } 2.1 \% \\
\text { RF: } 0\end{array}$ & $\begin{array}{l}\text { CA: } 4 \\
\text { LB: } 3\end{array}$ & $\mathrm{nr}$ & $\begin{array}{l}\text { CA: } 2 \\
\text { RF: } 0\end{array}$ & $\begin{array}{l}\text { CA: } 1 \\
\text { RF: } 0\end{array}$ \\
\hline Chronic PNP & $\begin{array}{l}\text { CA: } 0 \\
\text { RF: } 0\end{array}$ & CA: 0 & $\begin{array}{l}\text { CA: } 4 \\
\text { AAD: } 0\end{array}$ & $\begin{array}{l}\text { CA: } 1.0 \% \\
\text { RF: } 0.3 \%\end{array}$ & $\begin{array}{l}\text { CA: } 0 \\
\text { LB: } 0\end{array}$ & $\mathrm{nr}$ & $\begin{array}{l}\text { CA: } 0 \\
\text { RF: } 0\end{array}$ & $\begin{array}{l}\text { CA: } 0 \\
\text { RF: } 0\end{array}$ \\
\hline$P V S$ & $\begin{array}{l}\text { CA: } 0 \\
\text { RF: } 0\end{array}$ & CA: 2 & $\begin{array}{l}\text { CA: } 5 \\
\text { AAD: } 0\end{array}$ & $\begin{array}{l}\text { CA: } 0 \\
\text { RF: } 0\end{array}$ & $\begin{array}{l}\text { CA: } 0 \\
\text { LB: } 0\end{array}$ & $\begin{array}{l}\text { CA: } 0 \\
\text { RF: } 0\end{array}$ & $\begin{array}{l}\text { CA: } 0 \\
\text { RF: } 0 \\
\text { PV-narrowing } \\
\left.<50 \%^{\#}\right) \\
\text { CA: } 1 \\
\text { RF: } 5\end{array}$ & $\begin{array}{l}\text { CA: } 0 \\
\text { RF: } 0\end{array}$ \\
\hline $\begin{array}{l}\text { Atria-oesophag } \\
\text { fistula }\end{array}$ & $\begin{array}{l}\text { gCA: } 0 \\
\text { RF: } 0\end{array}$ & CA: 0 & $\begin{array}{l}\text { CA: } 0 \\
\text { AAD: } 0\end{array}$ & $\begin{array}{l}\text { CA: } 0 \\
\text { RF: } 0\end{array}$ & $\begin{array}{l}\text { CA: } 0 \\
\text { LB: } 0\end{array}$ & $\begin{array}{l}\text { CA: } 0 \\
\text { RF: } 0\end{array}$ & $\begin{array}{l}\text { CA: } 0 \\
\text { RF: } 0\end{array}$ & $\begin{array}{l}\text { CA: } 0 \\
\text { RF: } 0\end{array}$ \\
\hline $\begin{array}{l}\text { Vascular } \\
\text { complication + } \\
\text { major } \\
\text { bleedings }\end{array}$ & $\begin{array}{l}\text { CA: } 0 \\
\text { RF: } 0\end{array}$ & CA: 0 & $\begin{array}{l}\text { CA: } 5 \\
\text { AAD: } 1\end{array}$ & $\begin{array}{l}\text { CA: } 2.7 \% \\
\text { RF: } 4.6 \%\end{array}$ & $\begin{array}{l}\text { CA: } 2 \\
\text { LB: } 4\end{array}$ & $\begin{array}{l}\text { CA: } 0 \\
\text { RF: } 0\end{array}$ & $\begin{array}{l}\text { CA: } 2 \\
\text { RF: } 1\end{array}$ & $\begin{array}{l}\text { CA: } 0^{* * *} \text { ) } \\
\text { RF: } 1\end{array}$ \\
\hline \multirow[b]{2}{*}{ Follow-up } & $\frac{\frac{\text { AF-freedom }}{12 \text { mo after }}}{\underline{\text { index-ablation }}}$ & $\frac{\frac{\text { AF freedom }}{30 \text { mo after }}}{\underline{\text { index-ablation }}}$ & $\begin{array}{l}\frac{12 \text { mo free }}{\text { from chronic }} \\
\underline{\text { treatment }} \\
\underline{\text { failure }}\end{array}$ & $\frac{\frac{\text { AF freedom }}{12 \text { mo after }}}{\underline{\text { single index }}}$ & $\begin{array}{l}\frac{\text { AF freedom }}{90-365 \text { days }} \\
\underline{\text { after index }} \\
\underline{\text { ablation }}\end{array}$ & $\begin{array}{l}\frac{\text { AF freedom }}{3-12 \text { mo }} \\
\frac{\text { after index }}{\underline{\text { ablation }}}\end{array}$ & $\begin{array}{l}\frac{\text { AF freedom }}{3-12 \text { mo }} \\
\frac{\text { After index }}{\underline{\text { ablation }}}\end{array}$ & $\begin{array}{l}\frac{\text { AF freedom }}{3-12 \text { mo }} \\
\frac{\text { after index }}{\underline{\text { ablation }}}\end{array}$ \\
\hline & $\begin{array}{l}\text { CA: } \\
\text { PAF group: } \\
\text { 77\% } \\
\text { Persistent AF } \\
\text { group: } 48 \% \\
\\
\text { RF: } \\
\text { PAF group: } \\
\text { 72\% free from } \\
\text { recurrence }\end{array}$ & CA: $61.6 \%$ & $\begin{array}{l}\text { CA: } 69.9 \% \\
\text { AAD: } 7.3 \% \\
\text { Cross-over } \\
\text { AAD } \rightarrow \text { CA: } \\
79 \%\end{array}$ & $\begin{array}{l}\text { CA: } 54.2 \% \\
\text { RF: } 54.4 \%\end{array}$ & $\begin{array}{l}\text { CA: } 63 \% \\
\text { RF: } 73 \%\end{array}$ & $\begin{array}{l}\text { Intention to } \\
\text { treat: } \\
\text { CA: } 43 \% \\
\text { RF: } 58 \% \\
\text { On treatment: } \\
\text { CA: } 38 \% \\
\text { RF: } 53 \%\end{array}$ & $\begin{array}{l}\text { CA: } 46 \% \\
\text { RF: } 34 \%\end{array}$ & $\begin{array}{l}\text { Repeat ablation } \\
\text { during } \\
\text { follow-up: } \\
\text { CA: } 24 \% \\
\text { RF: } 0 \%\end{array}$ \\
\hline
\end{tabular}

AAD, antiarrhythmic drug; AF, atrial fibrillation; CA, cryoablation; LB, laser balloon; IQR, interquartile range; mo, month; p, patients; PAF, paroxysmal atrial fibrillation; PE/tamp, pericardial effusion/pericardial tamponade; PNP, phrenic nerve palsy; PVS, pulmonary vein stenosis; PV, pulmonary veins; RF, radio frequency ablation; ${ }^{*}$ Kojodjojo P. et al. 2010: all baseline characteristics refer to the subgroup of patients with PAF; ${ }^{* * *}$ Thromboembolic events; ${ }^{* * *}$ Hemoptysis secondary to transient hematoma surrounding the right inferior PV; ${ }^{\#}$ Not graded as complication.

\section{Methods}

\subsection{Study Design}

This is a prospective multicenter and multinational cohort study comparing safety and efficacy of either radiofrequency ablation (RF) or cryoballoon ablation (CA) for pulmonary vein isolation (PVI) in patients with atrial fibrillation. To avoid selection bias all participating centers are predefined as either "RF center" or "CA center" according to their first-line ablation technique in clinical routine. In centers offering both techniques (RF and CA) the treating physician may have the individual choice according to his clinical judgement, but only patients treated with the predefined "first-line" technique (according to the definition of either being "RF center" or "CA-center") will be included into the study. All centers have to provide the experience of at least 50 ablations with regard to their designated "first-line" technique before participating in the study. Although this number may not guarantee experienced operators in all centers under any condition, it reflects actual clinical routine of a rapidly spreading therapeutic intervention and also has been used in the study protocol of FIRE and ICE [3] [16]. Participating centers have to integrate all consecutive interventions of their first-line technique into the study. To insure the consecutiveness of recruitment and thereby reduce the risk of selection bias, the study centers have to announce each single patient selected for PVI to the coordinating center in Ludwigshafen before starting the procedure.

\subsection{Study Target Parameters}

The primary objective of the FREEZE cohort study is to evaluate efficacy of CA based pulmonary vein isolation (PVI) as compared to RF in a large volume of patients with paroxysmal or persistent AF treated in experienced 
centers. Therefore, the rate of patients free of AF recurrences lasting $\geq 30$ seconds during a follow-up of 12 months after ablation will statistically be compared between both techniques. This evaluation includes the differentiation between recurrences occurring within or later than 3 months after ablation. Differences in baseline characteristics of the patients in both groups will be considered in a multivariate statistical model. The secondary objectives are summarized as follows:

- Primary success rates with respect to completeness of PVI.

- Comparison of complication rates (any complications) during a 12 months follow-up period.

- Evaluation of specific complications with respect to phrenic nerve palsy, PV stenosis, and atrioesophageal fistula.

- Radiation exposure time and total duration of the examination.

- Clinical course including all cause death, non fatal events like stroke, minor stroke, bleeding, syncope, myocardial infarction, embolism, thrombosis, rehospitalization, repeat ablation, cardioversions, device implantation.

- Quality of life (EurQual 5d).

- Evaluation of specific procedural aspects:

o Efficacy (AF recurrence rates as defined above), safety (complication rates), and procedural parameters in cryoballoon or RF ablation as means for assessing advantages of pre-procedural computed tomography (CT) or magnetic resonance tomography (MRT) to evaluate 3D anatomy of the left atrium and pulmonary veins.

o Persistent AF: analysis of procedural aspects in CA with respect to their impact on clinical efficacy.

o Real-time ECG-monitoring during CA: evaluation of a microcircular mapping catheter with respect to its effect on the ablation outcome and safety.

Comparisons regarding secondary target parameters between both ablation techniques will be performed using descriptive statistics. In addition multivariate regression analysis will be used for adjustment of potential confounders, which are differently distributed in both groups at baseline.

\subsection{Study Population}

In general, adult patients with PAF or persistent AF (duration $<1$ year) can be enrolled into the study. Eligible patients must have had at least two episodes with AF within the last three months, one episode documented by ECG. The detailed inclusion and exclusion criteria are listed in Table 2.

Table 2. Selection of participating patients.

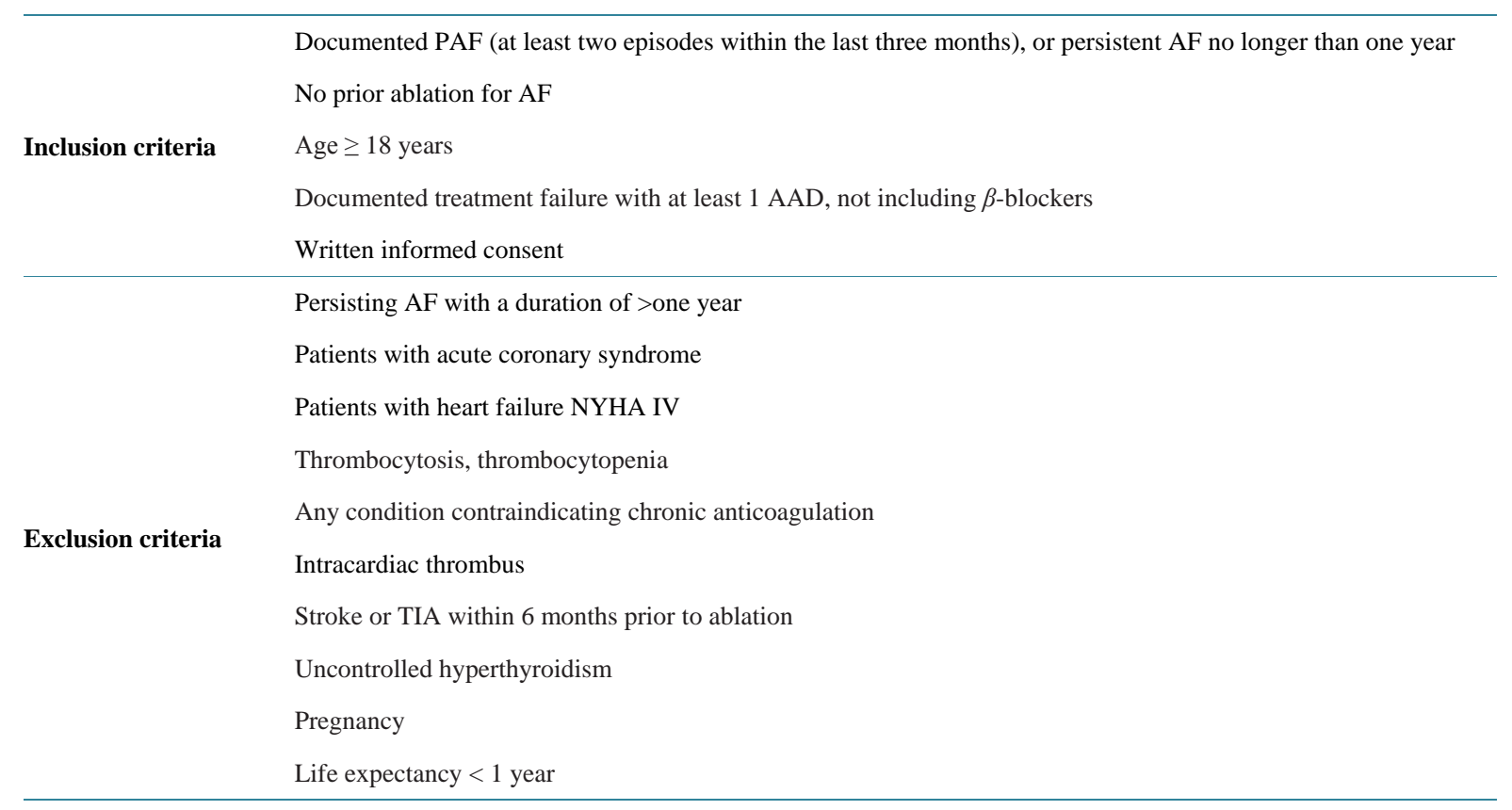




\subsection{Start of the Study and Follow-Up}

Patient's enrolment started in April $1^{\text {st }}$ 2011. All patients are monitored during the hospital stay for at least 24 48 hours after the intervention. Clinical visits are performed according to the local standards of care policies.

In case of symptoms suggestive for PV stenosis, each participating center will initiate further diagnostic procedures to its own discretion. Moreover, a total of 200 CA-treated patients will get either a MR or CT scan 6 12 months after ablation to definitively rule out PV stenosis. However, the decision to perform MRI/CT scans remains at the discretion of the physician responsible for the individual patient and will be done according to local routine procedures.

Furthermore, participating centers are asked to organize Holter-ECG monitoring recordings (up to 7 days of duration) three and twelve months after the index intervention to screen for symptomatic or asymptomatic atrial arrhythmias. Performance of Holter-monitoring may be adapted to the local capabilities and routine procedures. In addition, each center may add follow-up information from clinical visits based on the local policies and standards of care.

Finally, a telephone interview with all patients will be performed by the Institut für Herzinfarktforschung 12 months after the ablation procedure. All reported critical complications and adverse events will be validated by an independent critical event committee.

In case of AF recurrence during follow-up, a second procedure can be performed. The "re-do" procedure of choice for the recurrence may be a cryoballoon based approach again or a different modality according to the physicians' decision and preference. The "re-do" procedure must be reported to the cohort-study supervision team in the Institut für Herzinfarktforschung in Ludwigshafen, Germany.

\subsection{CA Procedure}

Before starting the therapeutic intervention all patients undergo transthoracic echocardiography to assess left atrium diameter and left ventricular ejection fraction. In addition trans-oesophageal echocardiography is performed to rule out left atrial thrombus formation prior to ablation.

After venous and arterial access, a single or double transseptal puncture is performed. Pulmonary vein potentials must be recorded at least before and after PV isolation with a circular mapping catheter. To guide the PV potentials during the cryoballoon freezes a 6-pole microcircular mapping catheter may be used (Achieve Mapping Catheter ${ }^{\circledR}$, Medtronic), which can be introduced into the central lumen of the cryoballoon catheter. In this case, the time to isolation of the treated vein should be determined and reported. In all patients with an intended use of the small $23 \mathrm{~mm}$ cryoballoon an imaging exploring the individual PV anatomy has to be performed prior to balloon therapy. Imaging may be performed using cardiac MRI, CT scan or PV angiography. The treatment of a left common ostium is left to the decision of the physician, and the choice of the cryoballoon size is left to the experience of the participating center. A single big balloon strategy (28 $\mathrm{mm}$ cryoballoon) only or an individualized approach using $28 \mathrm{~mm}$ or $23 \mathrm{~mm}$ cryoballoons according to the diameter of the PVs may be performed. In all patients at least 2 cryoenergy applications should be performed in each PV. Additional cryoenergy applications can be delivered to achieve complete PV isolation. Additional touch-up freezes with a conventional cryocatheter (Freezor MAX, CryoCath, Medtronic) or an RF catheter can be performed, if necessary. In all patients, the aim is to completely isolate the PVs. The upper limit of cryo-energy applications depends on the procedure duration and the clinical condition of the patient and is left to the physician's decision. Continuous monitoring of the phrenic nerve during ablation of the right superior and inferior PV either by fluoroscopy or by pacing manoeuvers should be performed in all patients to reduce the risk of phrenic nerve palsy.

\subsection{RF Ablation Procedure}

The RF ablation strictly has to follow the international accepted techniques described in detail in recent publications [17] [18]. Documentation includes ablation systems and catheters, tip-electrode-size and tip-electrodes as well as procedural characteristics (e.g. circumferential PV ablation, segmental PV isolation, additional lesions).

\subsection{Medication}

All patients should be anti-coagulated using phenprocoumon aiming an INR of 2.0 - 3.0 for at least 3 months after the index procedure. Long-term anticoagulation will be applied according to the current guidelines using 
the CHA2DS2-VASc score as basis for decision [19]. During the ablation procedure, the activated clotting time must be kept between 300 and 400 seconds by intravenous heparin administration.

\subsection{Electronic Case Record Form (eCRF) ${ }^{1}$}

An electronic CRF has been developed by the Institut für Herzinfarktforschung Ludwigshafen and is selfexplaining. To facilitate the data entry, the definitions of the various parameters will be accessible by a simple mouse click behind the related question in the CRF. Data will be entered via an SSL-secured Internet line.

For data entry, each study coordinator at each participating center receives an individual login information for the eCRF. The data base will be kept on the Server of the Institut für Herzinfarktforschung Ludwigshafen. Data are entered by each participating center directly into the internet based electronic CRF, and are immediately tested for plausibility in order to prevent queries. Only complete CRFs are accepted for statistical analysis.

\subsection{Statistical Analysis}

FREEZE as a non-interventional study has been designed to approach the evidence level of a randomized controlled trial as far as possible. Therefore, the sample size has been determined with the following assumptions: 4000 patients in total are necessary to show equivalence with regard to the primary efficacy endpoint (AF recurrence during 12 months of follow-up) with an equivalence level of $5 \%$ (test level 5\%, power $80 \%$ ).

Safety and efficacy target parameters will be statistically compared between both treatment techniques in a descriptive way. Resulting p-values are measures of the association between treatment technique and target parameters. Additionally, the populations with PAF and permanent AF will be separately analysed.

As the clinical outcome will be influenced by a large number of factors, multivariate regression models will be used for adjustment of confounding baseline parameters and for identifying independent associations between the ablation technique and clinical outcome. Subgroup analysis will be performed for detecting patients who potentially have the largest benefit from either cryoballoon or radiofrequency ablation. Decision tree methods will be taken into consideration for further statistical analysis.

\subsection{Quality Evaluation and Management}

The "Institut für Herzinfarktforschung Ludwigshafen" will scan the data for completeness and plausibility. Non plausible data will be immediately queried, and random samples of the data entered into the database will be subject of audits.

\subsection{Monitoring}

$10 \%$ of the active sites will be randomly selected for validation of the data entered in the CRF against patients' medical charts (monitoring). Because of the expected high number of patients in some sites, monitoring will only be possible in a sample of randomly selected patients in these high volume sites. Monitors will have to ensure that each informed consent is available before they request access to the patient's medical files.

\subsection{Publication Policy}

After closure of the data base at the end of the study the Institut für Herzinfarktforschung Ludwigshafen will send a final report of the FREEZE Cohort Study to the Steering committee. Official owner of the FREEZE Cohort Study data is the steering committee, and its members will decide on the use and publication modalities in accordance with the local and European laws.

Publications will be prepared on the basis of the analyses of the Institut für Herzinfarktforschung Ludwigshafen. The steering committee is responsible for all publications associated with the FREEZE Cohort Study. The steering committee is free to install a publications committee that is responsible for the writing of the manuscript. Major criteria of publication rights include active cooperation within the Steering Committee and number of recruiting patients. The final manuscript must however receive the authorisation of the steering committee.

After a first general publication (which shall be published by all members of the steering committee) further

${ }^{1} \mathrm{CRF}$ may be obtained on special request from the corresponding author. 
publications may be authorised by the steering committee. It must be visible from the publication that these secondary publications are based on the FREEZE cohort study data.

\subsection{Ethics}

The study complies with the Declaration of Helsinki. Legal restrictions concerning ethical approval may vary in the different participating countries. It is therefore the responsibility of each steering committee member in each specific country that participates in the registry to warrant, that the protocol is reviewed and approved by a local ethical committee. All patients are informed orally and by written patient information forms. Only patients with written informed consent are included into the study.

\section{Selected Interim Results}

From the 35 participating centers twenty-nine are located in Germany. Interim analyses of the study confirm successful implementation and conduction of the study. In Table 3 some representative baseline characteristics of 1882 included patients are presented. The age was 56 - 71 years, 33.9\% of the included patients were female. There was a remarkable difference in the distribution of patients with persistent AF in between the groups, which cannot be interpreted at the present stage of the study. Furthermore, patients undergoing RF ablation had significantly more concomitant disease including hypertension or diabetes. Pre-treatment of the included patients with vitamin $\mathrm{K}$ antagonists was remarkably low. A detailed presentation and discussion of the results including clinical outcomes and complications will be done after completion of the whole study as scheduled in the end of 2015.

Table 3. Baseline characteristics of patients included into the FREEZE cohort study; interim analysis.

\begin{tabular}{|c|c|c|c|}
\hline & Total & CA & RF \\
\hline Number of freeze patients & 1882 & 964 (51.2\%) & $918(48.8 \%)$ \\
\hline Age on admission [years] & $64.0(56-7100)$ & $63.0(56.0-70.0)$ & $65.0(57.0-71.0)$ \\
\hline Female & $33.9 \%$ & $33.4 \%$ & $34.4 \%$ \\
\hline \multicolumn{4}{|l|}{ Type of AF } \\
\hline Paroxysmal AF & $58.9 \%(1108 / 1882)$ & $70.3 \%(678 / 964)$ & $46.8 \%(430 / 918)$ \\
\hline Persistent AF (lasting $<1$ year) & $41.1 \%(774 / 1882)$ & $29.7 \%(286 / 964)$ & $53.2 \%(488 / 918)$ \\
\hline Cardiac disease & $42.2 \%$ & $41.6 \%$ & $42.7 \%$ \\
\hline Concomitant diseases & $71.7 \%$ & $66.9 \%$ & $76.8 \%$ \\
\hline Hypertension & $63.5 \%$ & $59.7 \%$ & $67.6 \%$ \\
\hline Diabetes & $8.8 \%$ & $6.9 \%$ & $10.8 \%$ \\
\hline Renal failure (GFR < 60) & $4.2 \%$ & $3.5 \%$ & $4.9 \%$ \\
\hline COPD & $3.5 \%$ & $2.8 \%$ & $4.3 \%$ \\
\hline PAD & $1.4 \%$ & $1.6 \%$ & $1.2 \%$ \\
\hline Previous stroke & $2.6 \%$ & $2.1 \%$ & $3.1 \%$ \\
\hline \multicolumn{4}{|l|}{ Antithrombotic pretreatment } \\
\hline Vitamin-K-antagonist & $27.9 \%$ & $19.1 \%$ & $37.3 \%$ \\
\hline Platelet inhibitors & $3.6 \%$ & $4.6 \%$ & $2.5 \%$ \\
\hline CHA2DS2-vasc score & $2.0 \pm 1.4$ & $1.8 \pm 1.3$ & $2.1 \pm 1.4$ \\
\hline CHA2DS2-vasc score $\geq 2$ & $59.0 \%$ & $55.1 \%$ & $62.5 \%$ \\
\hline \multicolumn{4}{|l|}{ Cardiac imaging } \\
\hline LVEF [\%] & $55.0(55.0-60.0)$ & $60.0(55.0-60.0)$ & $55.0(55.0-60.0)$ \\
\hline LA diameter $[\mathrm{mm}]$ & $42.0(39.0-47.0)$ & $42.0(38.0-47.0)$ & $43.0(40.0-48.0)$ \\
\hline
\end{tabular}

AF, atrial fibrillation; CA, cryoablation; CI, confidence interval; COPD, chronic obstructive disease; GFR, glomerular filtration rate; LA, left atrium; LVEF, left ventricular ejection fraction; RF, radiofrequency ablation; OR, odds ratio. 


\section{Discussion}

From the background of the high incidence and prevalence of AF especially in elderly patients and the limitedpotential of drugs, pulmonary vein isolation by catheter ablation procedures becomes increasingly important in clinical routine. The cryoballoon technology was developed to simplify and shorten the therapeutic intervention and to additionally improve safety of PVI. However, until now it has not been shown convincingly that these objectives have been accomplished. Therefore, in addition to the ongoing randomized, controlled trial "FIRE and ICE” the real life comparison of CA and RF ablation for pulmonary vein isolation in a large prospective, multi-center, and multi-national cohort study is of great importance to:

a) show under which conditions either CA or RF is the treatment of choice in patients eligible for PVI;

b) further optimize the individual treatment with respect to clinical effectiveness and safety of both techniques;

c) contribute to the future developments in PVI-techniques aiming a further increase in efficiency and safety.

To reduce potential bias of various levels of technical skills only centers with a minimum of 50 index procedures participate in this study. Potential selection bias is limited by a strictly controlled consecutive enrolment of all patients.

With respect to safety, the development of esophageal-atrial fistula is one of the most deleterious complication. This however has not been reported so far using the cryoenergy technique (see also Table 1) [7]-[15] [20]-[22]. The most common complication of the cryoablation technique is the phrenic nerve palsy (PNP), and PNP incidences up to 13\% have been reported [10]. However, PNP appears to be a transient event in the vast majority of cases with a complete recovery within 12 months [8]-[15] [20]-[25]. Nevertheless, any effort has to be done to reduce the risk of PNP, which can be achieved by continuously monitoring the phrenic nerve activity during ablation. Furthermore, the ratio of PV diameter versusballoon size seems to be of relevance to allow a complete occlusion deep inside the right sided PVs. It remains one of the challenges of this study to get more information on how to avoid PNP in all patients.

Another serious complication is the development of pulmonary vein stenosis with an expected incidence up to 3\% of patients post CA [10] [14]. The intra PV balloon inflation may have a causal relationship to this adverse event. Since the PV ostia typically are oval and not circular, the individual adaptation of the cryoballoon for complete occlusion remains challenging. Some data indicate that the use of larger balloons of $28 \mathrm{~mm}$ diameter may reduce this problem, thereby avoiding pulmonary vein stenosis [6]. Pre-PVI imaging providing information on the 3-D anatomy of the left atrium and the pulmonary veins may contribute to the "best procedural CA-technique" in this respect, and will be tested in the present study.

Another challenge is the high rate of persistent AF in elderly patients promoted by concomitant structural heart diseases [26]. To date circumferential radio frequency ablation is the standard technique for the interventional treatment of persistent AF allowing a substrate modification of the left atrium beyond the elimination of PV triggers. So far, for treatment of persistent AF cryoballoon ablation using a single balloon strategy with either the smaller $(23 \mathrm{~mm})$ or the bigger $(28 \mathrm{~mm})$ balloon appears to be less effective [5]. This experience also is reflected by the interim data of the FREEZE cohort study shown in Table 3. In clinical routine the CA technique is obviously preferred in patients with persistent AF. Since PV isolation is the key of any AF ablation approach and additional substrate modification is required in persistent AF, it seems promising to combine ostial and antral effects of the cryoballoon technology using the $23 \mathrm{~mm}$ balloon in combination with the $28 \mathrm{~mm}$ balloons in a "double balloon” strategy. By this technique, the ablative effect of the $23 \mathrm{~mm}$ balloon is primarily located at the ostial level, whereas the $28 \mathrm{~mm}$ balloon predominantly allows an ablation at the antral level of the pulmonary veins. From the background of these considerations, it is another aim of the FREEZE-cohort study to compare this double balloon technique with actual standard care of an "antral" cryoablation using the $28 \mathrm{~mm}$ balloon alone.

All together, the present study will provide important additional information on safety and efficacy of pulmonary vein ablation in patients with paroxysmal and persistent AF. In addition, the study will give insights into the actual clinical course and quality of life of patients with AF and elevated cardiovascular risk. Finally this study will be the basis to better weigh out expenditures and risks of the interventional treatment of atrial fibrillation on the one side and clinical outcome on the other.

\section{Limitations of the Study}

FREEZE COHORT is an observational cohort study reflecting clinical practice and outcome under predefined 
study conditions. The outcome may be influenced by a large number of factors, and apparent associations between these confounders and clinical outcomes only can be presented in a descriptive manner potentially serving as a basis for new hypotheses. For identification of clinically important cause-effect relationships additional prospective and well targeted studies will then be necessary.

\section{Acknowledgements}

The FREEZE Cohort Study is supported by "Medtronic" and by the "Stiftung Institut für Herzinfarktforschung Ludwigshafen" (IHF). The "Stiftung Institut für Herzinfarktforschung" is a non-profit institute. The institute will be reimbursed by Medtronic for their services to cover the expenses that are imposed by the conduction of the study.

\section{References}

[1] Ball, J., Carrington, M.J., McMurray, J.J. and Stewart, S. (2013) Atrial Fibrillation: Profile and Burden of an Evolving Epidemic in the $21^{\text {st }}$ Century. International Journal of Cardiology, 167, 1807-1824. http://dx.doi.org/10.1016/j.ijcard.2012.12.093

[2] Haïssaguerre, M., Jaïs, P., Shah, D.C., Takahashi, A., Hocini, M., Quiniou, G., Garrigue, S., Le Mouroux, A., Le Méayer, P. and Clémenty, J. (1998) Spontaneous Initiation of Atrial Fibrillation by Ectopic Beats Originating in the Pulmonary Veins. New England Journal of Medicine, 339, 659-666. http://dx.doi.org/10.1056/NEJM199809033391003

[3] Cappato, R., Calkins, H., Chen, S.A., Davies, W., Iesaka, Y., Kalman, J., Kim, Y.H., Klein, G., Packer, D. and Skanes, A. (2005) Worldwide Survey on the Methods, Efficacy, and Safety of Catheter Ablation for Human Atrial Fibrillation. Circulation, 111, 1100-1105. http://dx.doi.org/10.1161/01.CIR.0000157153.30978.67

[4] Cappato, R., Calkins, H., Chen, S.A., Davies, W., Iesaka, Y., Kalman, J., Kim, Y.H., Klein, G., Natale, A., Packer, D. and Skanes, A. (2009) Prevalence and Causes of Fatal Outcome in Catheter Ablation of Atrial Fibrillation. Journal of the American College of Cardiology, 53, 1798-1803. http://dx.doi.org/10.1016/j.jacc.2009.02.022

[5] Neumann, T., Vogt, J., Schumacher, B., Dorszewski, A., Kuniss, M., Neuser, H., Kurzidim, K., Berkowitsch, A., Koller, M., Heintze, J., Scholz, U., Wetzel, U., Schneider, M.A., Hortskotte, D., Hamm, C. and Pitschner, H.J. (2008) Circumferential Pulmonary Vein Isolation with the Cryoballoon Technique-Results from a Prospective 3-Center Study. Journal of the American College of Cardiology, 52, 273-278. http://dx.doi.org/10.1016/j.jacc.2008.04.021

[6] Chun, K.-R.J., Schmidt, B., Metzner, A., Tilz, R., Zerm, T., Köster, I., Fürnkranz, A., Koektuerk, B., Konstantinidou, M., Antz, M., Ouyang, F. and Kuck, K.H. (2009) The "Single Big Cryoballoon” Technique for Acute Pulmonary Vein Isolation in Patients with Paroxysmal Atrial Fibrillation: A Prospective Observational Single Center Study. European Heart Journal, 30, 699-709. http://dx.doi.org/10.1093/eurheartj/ehn570

[7] Malmborg, H., Lönnerholm, S. and Blomström-Lundqvist, C. (2008) Acute and Clinical Effects of Cryoballoon Pulmonary Vein Isolation in Patients with Symptomatic Paroxysmal and Persistent Atrial Fibrillation. Europace, 10, 1277-1280. http://dx.doi.org/10.1093/europace/eun286

[8] Kojodjojo, P., O’Neill, M.D., Lim, P.B., Malcolm-Lawes, L., Whinnett, Z.I., Salukhe, T.V., Linton, N.W., Lefroy, D., Mason, A., Wright, I., Peters, N.S., Kanagaratnam, P. and Davies, D.W. (2010) Pulmonary Venous Isolation by Antral Ablation with a Large Cryoballoon for Treatment of Paroxysmal and Persistent Atrial Fibrillation: Medium-Term Outcomes and Non-Randomised Comparison with Pulmonary Venous Isolation by Radiofrequency Ablation. Heart, 96, 1379-1384. http://dx.doi.org/10.1136/hrt.2009.192419

[9] Vogt, J., Heintze, J., Gutleben, K.J., Muntean, B., Horstkotte, D. and Nölker, G. (2013) Long-Term Outcomes after Cryoballoon Pulmonary Vein Isolation. Journal of the American College of Cardiology, 61, 1707-1712. http://dx.doi.org/10.1016/j.jacc.2012.09.033

[10] Packer, D.L., Kowal, R.C., Wheelan, K.R., Irwin, J.M., Champagne, J., Guerra, P.G., Dubuc, M., Reddy, V., Nelson, L., Holcomb, R.G., Lehmann, J.W. and Ruskin, J.N., for the STOP AF Cryoablation Investigators (2013) Cryoballoon Ablation of Pulmonary Veins for Paroxysmal Atrial Fibrillation. Journal of the American College of Cardiology, 61, 1713-1723. http://dx.doi.org/10.1016/j.jacc.2012.11.064

[11] Schmidt, M., Dorwarth, U., Andresen, D., Brachmann, J., Kuck, K.H., Kuniss, M., Lewalter, T., Spitzer, S., Willems, S., Senges, J., Jünger, C. and Hoffmann, E. (2013) Cryoballoon versus RF Ablation in Paroxysmal Atrial Fibrillation: Results from the German Ablation Registry. Journal of Cardiovascular Electrophysiology, 25, 1-7. http://dx.doi.org/10.1111/jce.12267

[12] Bordignon, S., Chun, K.R.J., Gunawardene, M., Fuernkranz, A., Urban, V., Schulte-Hahn, B., Nowak, B. and Schmidt, B. (2013) Comparison of Balloon Catheter Ablation Technologies for Pulmonary Vein Isolation: The Laser versus 
Cryo Study. Journal of Cardiovascular Electrophysiology, 24, 987-994. http://dx.doi.org/10.1111/jce.12192

[13] Pokushalov, E., Romanov, A., Artyomenko, S., Baranova, V., Losik, D., Bairamova, S., Karaskov, A., Mittal, S. and Steinberg, J. (2013) Cryoballoon versus Radiofrequency for Pulmonary Vein Re-Isolation after a Failed Initial Ablation Procedure in Patients with Paroxysmal Atrial Fibrillation. Journal of Cardiovascular Electrophysiology, 24, 274279. http://dx.doi.org/10.1111/jce.12038

[14] Malmborg, H., Lönnerholm, S., Blomström, P. and Blomström-Lundqvist, C. (2013) Ablation of Atrial Fibrillation with Cryoballoon or Duty-Cycled Radiofrequency Pulmonary Vein Ablation Catheter: A Randomized Controlled Study Comparing the Clinical Outcome and Safety; the AF-COR Study. Europace, 15, 1567-1573. http://dx.doi.org/10.1093/europace/eut104

[15] Pérez-Castellano, N., Fernández-Cavazos, R., Moreno, J., Canadas, V., Conde, A., González-Ferrer, J.J., Macaya, C. and Pérez-Villacastín, J. (2014) The COR Trial: A Randomized Study with Continuous Rhythm Monitoring to Compare the Efficacy of Cryoenergy and Radiofrequency for Pulmonary Vein Isolation. Heart Rhythm, 11, 8-14. http://dx.doi.org/10.1016/j.hrthm.2013.10.014

[16] FIRE and ICE Trial (2014) A Controlled, Prospective, Non-Inferiority, Parallel-Group, Randomized, Interventional, Open, Blinded Outcome Assessment, Multi-Center Trial, Comparing Efficacy and Safety of Isolation of the Pulmonary Veins with a Cryoballoon Catheter versus a Radiofrequency Ablation with a ThermoCool Catheter in Patients with Paroxysmal Atrial Fibrillation. ClinicalTrials.gov Identifier NCT01490814.

[17] Raviele, A., Natale, A., Calkins, H., Camm, J.A., Cappato, R., Ann Chen, S., Connolly, S.J., Damiano Jr., R., De Ponti, R., Edgerton, J.R., Haïssaguerre, M., Hindricks, G., Ho, S.Y., Jalife, J., Kirchhof, P., Kottkamp, H., Kuck, K.H., Marchlinski, F.E., Packer, D.L., Pappone, C., Prystowsky, E., Reddy, V.K., Themistoclakis, S., Verma, A., Wilber, D.J. and Willems, S. (2012) Venice Chart International Consensus Document on Atrial Fibrillation Ablation: 2011 Update. Journal of Cardiovascular Electrophysiology, 23, 890-923. http://dx.doi.org/10.1111/j.1540-8167.2012.02381.x

[18] Calkins, H., Kuck, K.H., Brugada, J., Cappato, R., Camm, A.J., Chen, S.A., et al. (2012) 2012 HRS/EHRA/ECAS Expert Consensus Statement on Catheter and Surgical Ablation of Atrial Fibrillation: Recommendations for Patient Selection, Procedural Techniques, Patient Management and Follow-Up, Definitions, Endpoints, and Research Trial Design. Heart Rhythm, 9, 632-696. http://dx.doi.org/10.1016/j.hrthm.2011.12.016

[19] Camm, A.J., Lip, G.Y.H., De Caterina, R., Savelieva, I., Atar, D., Hohnloser, S.H., Hindricks, G., Kirchhof, P., et al. (2012) 2012 Focused Update of the ESC Guidelines for Management of Atrial Fibrillation: An Update of the 2010 ESC Guidelines for the Management of Atrial Fibrillation. Development with the Special Contribution of the European Heart Rhythm Association. European Heart Journal, 33, 2719-2747. http://dx.doi.org/10.1093/eurheartj/ehs253

[20] Kühne, M., Suter, Y., Altmann, D., Ammann, P., Schaer, B., Osswald, S. and Sticherling, C. (2010) Cryoballoon versus Radiofrequency Catheter Ablation of Paroxysmal Atrial Fibrillation: Biomarkers of Myocardial Injury, Recurrence Rates, and Pulmonary Vein Reconnection Patterns. Heart Rhythm, 7, 1770-1776. http://dx.doi.org/10.1016/j.hrthm.2010.08.028

[21] Tse, H.F., Reek, S., Timmermans, C., Lee, K.L., Geller, J.C., Rodriquez, L.M., Ghaye, B., Ayers, G.M., Crijns, H.J., Klein, H.U. and Lau, C.P. (2003) Pulmonary Vein Isolation Using Transvenous Catheter Cryoablation for Treatment of Atrial Fibrillation without Risk of Pulmonary Vein Stenosis. Journal of the American College of Cardiology, 42, 752758. http://dx.doi.org/10.1016/S0735-1097(03)00788-5

[22] Schmidt, B., Antz, M., Ernst, S., Ouyang, F., Falk, P., Chun, J.K. and Kuck, K.H. (2007) Pulmonary Vein Isolation by High Intensity Ultrasound: First-in-Man Study with a Steerable Balloon Catheter. Heart Rhythm, 4, 575-584. http://dx.doi.org/10.1016/j.hrthm.2007.01.017

[23] Guiot, A., Savouré, A., Godin, B. and Anselme, F. (2012) Collateral Nervous Damages after Cryoballoon Pulmonary Vein Isolation. Journal of Cardiovascular Electrophysiology, 23, 346-351. http://dx.doi.org/10.1111/j.1540-8167.2011.02219.x

[24] Van Belle, Y., Janse, P., Theuns, D., Szili-Torok, T. and Jordaens, L. (2008) One Year Follow-Up after Cryoballoon Isolation of the Pulmonary Veins in Patients with Paroxysmal Atrial Fibrillation. Europace, 10, 1271-1276. http://dx.doi.org/10.1093/europace/eun218

[25] Linhart, M., Bellmann, B., Mittmann-Braun, E., Schrickel, J.W., Bitzen, A., Andrié, R., Yang, A., Nickenig, G., Lickfett, L. and Lewalter, T. (2009) Comparison of Cryoballoon and Radiofrequency Ablation of Pulmonary Veins in 40 Patients with Paroxysmal Atrial Fibrillation: A Case Control Study. Journal of Cardiovascular Electrophysiology, 20, 1343-1348. http://dx.doi.org/10.1111/j.1540-8167.2009.01560.x

[26] Nieuwlaat, R., Capucci, A., Camm, A.J., Olsson, S.B., Andresen, D., Davies, D.W., Cobbe, S., Breithardt, G., Le Heuzey, J.Y., Prins, M.H., Lévy, S. and Crijns, H.J., on Behalf of the Euro Heart Survey Investigators (2005) Atrial Fibrillation Management: A Prospective Survey in ESC Member Countries: The Euro Heart Survey on Atrial Fibrillation. European Heart Journal, 26, 2422-2434. http://dx.doi.org/10.1093/eurheartj/ehi505 


\section{Appendix}

\section{Steering Committee}

Cryoablation arm: Ellen Hoffman (Chairperson), Burghard Schuhmacher (Co-Chairman), Julian Chun, Malte Kuniss, Jürgen Vogt.

Radiofrequency arm: Karl-Heinz Kuck (Co-Chairman), Dietrich Andresen, Thomas Arentz, Johannes Brachmann, Lars Eckard, Thorsten Lewalter, S. Willems, Stepfan G. Spitzer, Jürgen Tebbenjohanns.

Design and Coordination: Jochen Senges, Martin Schmidt, Uwe Dorwarth, Ralf Meyer.

Biometry: Steffen Schneider.

Manuscript: Bernhard Rauch.

\section{Participating Centers}

AUSTRIA: Linz: Allgemeines Krankenhaus Linz (Steinwender C.), GERMANY: Asklepios Klinik St. Georg (Kuck K.H.), Hamburg; Städt. Klinikum München-Bogenhausen (Hofmann E., Dorwarth U.); Kerckhoff-Klinik Bad Nauheim (Kuniss M.); Herz und Diabeteszentrum Nordrhein-Westfalen, Bad Oeynhausen (Vogt J., Nölker D.); Klinikum Hildesheim, (Tebbenjohanns J.); Elisabeth Krankenhaus Essen (Sabin G.); Klinikum Siloah Hannover (Franke A.); Universitäres Herzzentrum Eppendorf, Hamburg (Willems S.); Vivantes Klinikum am Urban Berlin (Andresen D.); Städtisches Klinikum Frankfurt-Höchst (Sen S.); Herz-und Gefäßklinik Bad Neustadt (Deneke T.); Klinikum Bielefeld (Stellbrink C.); Praxisklinik Herz und Gefäße, Dresden (Spitzer S.); Deutsches Herzzentrum Berlin (Fleck E., Gerds-Li H.); Cardioangiologisches Zentrum Bethanien, CCB, Frankurt (Chun K.R.J.); Klinikum Traunstein (Moshage W.); Universitätsklinik Schleswig Holstein, Lübeck (Thiele H.); Universitätsklinik Bonn (Schrickel J.); Klinikum Coburg (Brachmann J.); Herzzentrum Münster (Eckardt L.); Schwarzwald-Baar-Klinikum Villingen-Schwenningen (Jung W.); Isar-Herzzentrum, München (Lewalter T.); Klinikum Ingolstadt (Seidl K.); Klinikum Aschaffenburg (Groschup G.); Städtische Kliniken Mönchengladbach (Lickfett L.); Universitätsmedizin Mainz (Münzel T.); Universitätsklinikum Heidelberg (Katus H., Hardt S.);Klinikum Lippe-Detmold (Tebbe, U.); Herzzentrum Duisburg (Kattenbeck K.).

GREECE: Evangelimos General Hospital, Athens (Efremidis M.).

SOUTH AFRICA: Sunninghill Hospital, Johannesburg (Stanley A.); Panorama Medi-Clinic, Panorama, (Ghopal R.R.); Milpark Hospital, Parktown West (Obel I.W.P.).

SPAIN: University Hospital Virgen de la Arrixaca, El Palmar-Murcia (Garcia Aleberola A.);

USA: Mission Hospital, Asheville, NC (Souza J.J.).

\section{Case Report Form (CRF)}

The CRF can be obtained on request from the corresponding author. 
Scientific Research Publishing (SCIRP) is one of the largest Open Access journal publishers. It is currently publishing more than 200 open access, online, peer-reviewed journals covering a wide range of academic disciplines. SCIRP serves the worldwide academic communities and contributes to the progress and application of science with its publication.

Other selected journals from SCIRP are listed as below. Submit your manuscript to us via either submit@scirp.org or Online Submission Portal.
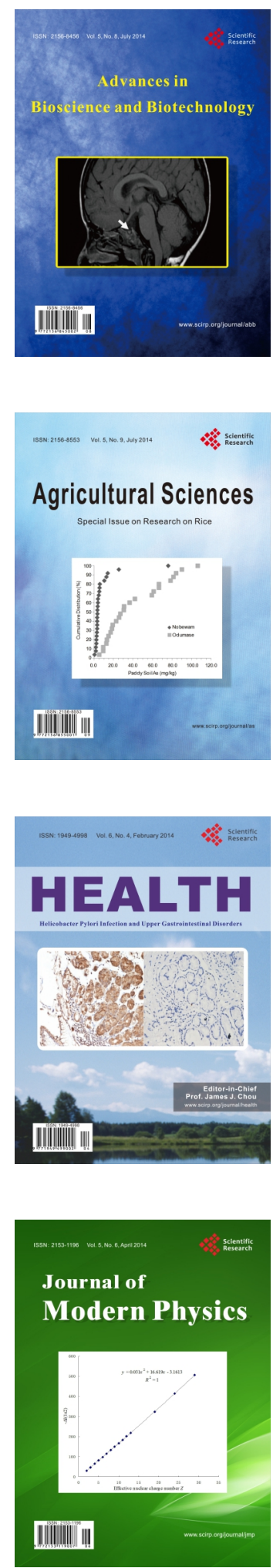
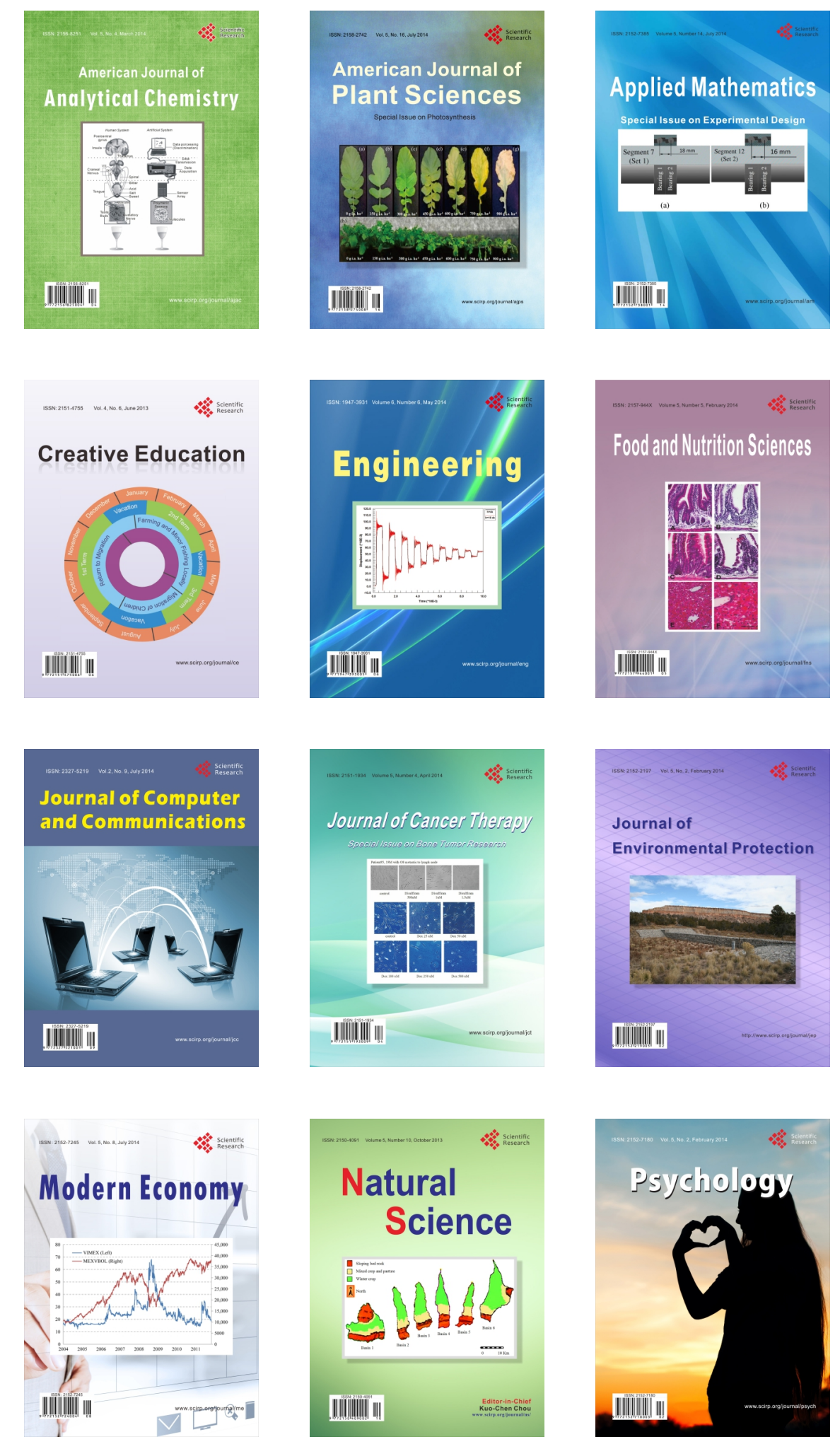